\title{
ANALYSIS OF DATA COMPLETENESS IN THE REGISTER OF REAL ESTATE PRICES AND VALUES USED FOR REAL ESTATE EVALUATION ON THE EXAMPLE OF KOSZALIN DISTRICT IN THE YEARS 2010-2016
}

Leszek Dawid, Ph.D., Eng.

\begin{abstract}
The aim of this paper is to analyse the completeness of data contained in the register of real estate prices and values. Transactions concerning parcels with residential buildings located on them were studied. On the basis of, among others, data obtained from this register, real estate valuers evaluate real estate. The following market characteristics were selected for the analysis: transaction price, usable area, year of building construction, construction material of building walls, number of storeys, plot size, and others. The data were obtained from the District Office in Koszalin. The study was conducted on the example of Koszalin district in the years 2010-2016. The technique of quantitative and qualitative analysis of documents was used in the study.
\end{abstract}

Keywords: register of real estate prices and values, Koszalin district

JEL classification: R52, K11, P14, H27 


\section{Introduction}

In the Real Property Management Act of 21 August 1997 (the Act, 1997a), Art. 155. 1. stipulates that in real property valuation all available necessary data on the real estate are used.

In this article, the author studies the register of prices and values, which is an element of Land and Building Register. Pursuant to Paragraph 1. $§ 74$. of the Ordinance of the Minister of Infrastructure and Construction on the land and building register of 10 June 2016 (The Ordinance, 2016), the district administrator keeps the register of the real estate prices specified in notarial deeds, and of the real estate value specified by real estate valuers in valuation surveys, the excerpts from which are passed to the land register. In addition to the prices and values referred to in section 1, the following data are subject to registration:

1) the address of the real estate location;

2) the numbers of record parcels included in the real estate:

3) the type of the real estate;

4) the area of the land property;

5) the date of the notarial deed conclusion or value determination; and

6) other available data on the real properties and their components.

The specification of the conceptual model of the register of prices and values is included in Attachment 7 to the Ordinance (The Ordinance, 2016). In the case of a parcel, the register of prices and values should contain, among others, the following data: transaction/valuation date, gross transaction price, the plot size in $\mathrm{m}^{2}$, the right - the object of the transaction, the type of market, the seller, the buyer, the type of transaction, the type of the real estate, land and mortgage register, the precinct, usable area $\left(\mathrm{m}^{2}\right)$, footprint area from the map, class and land type in the plot, existing utilities, building erection date, the construction material of the building walls, the technical condition of the building, the number of storeys, and others. When completing the register of prices and values, the office workers in District Offices base on notarial deeds and excerpts from valuation surveys obtained from real estate valuers

Pursuant to the Act of 23 April 1964 Civil Code-Art. 158 (Civil Code, 1964), the agreement obliging to the transfer of the real estate ownership should be concluded in the form of a notarial deed. Notarial deeds are prepared by notaries. Pursuant to $\S 1-4$ Art. 80 of the Notary Public Act of 14 February 1991 (the Act, 1991), notaries are obliged, among others, to prepare acts and documents in a clear and transparent manner, and, during the performance of a notarial act, to watch over the proper protection of the rights and legitimate interest of the parties and other persons for whom this act may produce legal effects. Moreover, a notary is obliged to provide 
the parties with necessary explanations concerning the notarial act performed, and, by means of a protocol, to correct inaccuracies, typographical, arithmetic errors or other obvious mistakes. In the case of the transfer of the real estate ownership, a notary should draw up related deeds and documents in a clear, transparent manner, and watch over the proper protection of the rights of the parties. However, the Act does not include any guidelines what obligatory data concerning the description of the real estate should be included in the notarial deed when executing a real estate transaction (Kokot 2015).

Disclosing data from the register of prices and values is regulated by a number of acts. They include, among others:

1. The Act of 17 May 1989, Surveying and Cartographic Law (Journal of Laws of 2015, item 520 as amended).

2. The Ordinance of the Minister of Regional Development and Construction of 29 March 2001 on land and building register (Journal of Laws of 2015, item 542 as amended).

3. The Ordinance of the Minister of Administration and Digitalisation of 9 July 2014 on the access to the National Geodetic and Cartographic Resources, the issuance of licence and the template of Fee Calculation Document (Journal of Laws of 2014, item 917 as amended) (The Ordinance, 2014).

4. The Ordinance of the Minister of Administration and Digitalisation of 5 September 2013 on the organisation and conditions of keeping the National Geodetic and Cartographic Resource (Journal of Laws of 2013, item 1183 as amended) (The Ordinance, 2013b).

5. The Real Property Management Act of 21 August 1997 (Journal of Laws of 2015, item 782 as amended).

6. The Act of 14 June 1960 Administrative Procedure Code (Journal of Laws of 2016, as amended).

7. Personal Data Protection Act of 29 August 1997 (Journal of Laws of 2015, item 2135 as amended) (the Act, 1997b).

8. Stamp Duty Act of 16 November 2006 (Journal of Laws of 2015, item 783 as amended) (the Act, 2006).

The aim of this paper is to analyse the completeness of the data obtained from the register of prices and values, concerning parcels with residential function. On the basis of the data obtained from the register of prices and values, among others, real estate valuers make the evaluation of the real estate. The register of prices and values is an important source of information about real properties (Bydłosz, Cichociński, Parzych, 2010; Budzyński, 2012; Hopfer, Cegielski, Pietrzak, 2012), but there are cases with the problem of the quality of these data (Konowalczuk, 
2014; Foryś, Kokot, 2001) and their completeness. The lack of data is the reason for which a certified real estate valuer must reject a specific transaction, and considering a small number of transactions on the local market, real estate valuation becomes problematic. The following market characteristics were selected for the analysis: transaction price, usable area, type of market, type of the rights to the land, year of construction of the building, construction material of the building walls, technical condition of the building, the number of storeys, the plot size, and others. The data were obtained from the District Office in Koszalin. The study was conducted on the example of Koszalin district in the years 2010-2016 to check whether the quality of data changed in this period of time. 113 transactions were analysed.

\section{Research area and research methods}

Koszalin district is situated in the north-eastern part of West Pomeranian Voivodeship. The population is about 64,000 people. Its area is $1,669 \mathrm{~km}^{2}$, of which $34.1 \%$ is arable land, $42.8 \%$ is forest and woodland, and $23.1 \%$ are other lands. The district includes eight communes, namely: Bobolice, Polanów, Sianów, and Mielno with urban and rural status, as well as Będzino, Biesiekierz, Manowo, and Świeszyno with rural status. In total, in Koszalin district, excluding Koszalin which has the status of an independent township, there are 322 localities. In terms

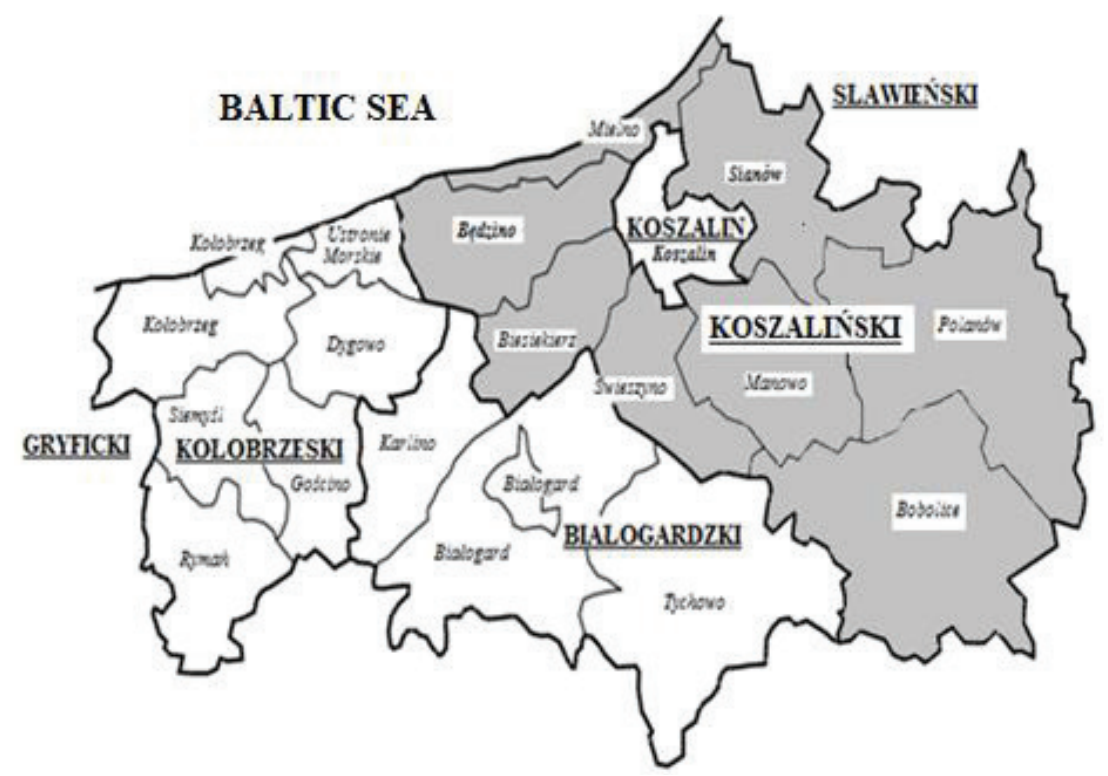

Figure 1. Part of West Pomeranian Voivodeship with districts and communes Source: author's own study. 
of the population, the biggest of Koszalin district communes is Sianów, an urban and rural commune (the population of about 13,300), and the smallest is Mielno, an urban and rural commune with the population of about 5,100. In Koszalin district, rural population prevails over urban population and is $78 \%$. Koszalin district borders Kołobrzeg district to the west, Białogard district to the southwest, Szczecinek to the south, Bytów to the east, and Sławno to the northeast. The northern border of the district is designated by about thirty-kilometre coastline of the Baltic Sea. The research area is presented in Figure 1.

The study is based on the technique of a quantitative and qualitative analysis of documents. It consists in obtaining data from different source materials of a formalised character. In the discussed case, the source materials were obtained from the register of prices and values from District Office in Koszalin.

\section{The analysis of data completeness in the register of prices and values}

Certified real estate valuers pay for the obtained transactions in the register of prices and values (the Act, 1989; the Act, 2006). They expect the data on them to be complete, and that on their basis it is possible to make the real estate evaluation (The Ordinance, 2004). In the case of the valuation of the analysed type of the real estate, the necessary information for the valuation from the register of prices and values is primarily as follows: the usable area of the building, transaction price, transaction date, real estate location, plot size, year of building construction, construction material of building walls, number of storeys, etc. The above characteristics were analysed in terms of completeness expressed as the percentage of transactions with a correctly described quality to the number of all transactions in the analysed period.

In the years 2010-2016 in Koszalin district, the total of 113 of purchase sale transactions of parcels with residential function were concluded. In the analysed period, no entries were made into the register of prices and values with regard to the real estate value. It probably arises from the fact that real estate valuers do not send excerpts from valuation surveys to the land and building register although they are obliged to do this (the Act 1997a, Art. 158). Table 1 presents the number of real estate transactions in the consecutive years of the analysis.

Table 1. The number of purchased buildings in Koszalin district in the years 2010-2016

\begin{tabular}{|l|c|c|c|c|c|c|c|}
\hline $\begin{array}{c}\text { Parcels with residential } \\
\text { function }\end{array}$ & 2010 & 2011 & 2012 & 2013 & 2014 & 2015 & 2016 \\
\hline Number & 11 & 22 & 11 & 2 & 0 & 19 & 48 \\
\hline
\end{tabular}

Source: author's own study. 
Due to the similar distribution of data availability for the following communes: Bobolice, Sianów, Mielno (municipal rights since 1 January 2017), and Polanów, they were not divided into an urban and rural part. The biggest number of transactions was in 2016 - 48, the smallest number in 2014 when no transactions were recorded. As far as individual communes of the district are concerned, the biggest number of transactions in the analysed period were concluded in Mielno commune -48 , which constituted about $42 \%$ of all transactions, then in Bobolice commune -18 transactions, which constituted about $16 \%$ of the total number of transactions. The fewest transactions were recorded in Polanów commune -4 transactions, which constituted about $4 \%$ of the analysed transactions. Figure 2 presents the number of transactions in the individual communes of Koszalin district.

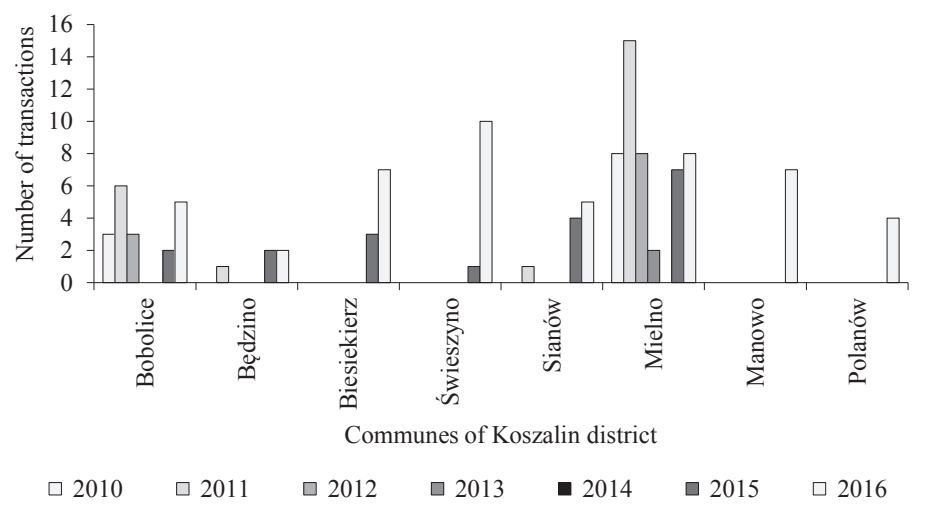

Figure 2. Transactions of parcels with a residential function in the individual communes of Koszalin district in the years 2010-2016

Source: author's own study based on the data obtained from Koszalin Office.

The completeness of the data from the register of prices and values on the usable areas of buildings is very low. For the analysed period in Koszalin district communes, it is only $7 \%$. The highest data availability was in Sianów commune in $2011-100 \%$, and in Świeszyno commune in 2015 , also $100 \%$. However, it resulted from the fact that those were single complete transactions in a given year. In the remaining years of the analysis in the majority of transactions in the communes, there is no information about the usable area, which is shown in Table 2.

An important role in the evaluation of the analysed type of the real estate market is played by the year of a building construction. As a rule, newer buildings have a higher standard of finishing, are built of materials with better heat transfer coefficient, and are more functional. From the available data it arises that in the analysed period, the information about the construction 
year occurs only in 13\% of cases. Full data are for 2011 and 2015 in Bobolice commune, in Sianów commune in 2011, and in Świeszyno commune in 2015. It results from the fact that those are single cases of transactions in a given year. In Mielno commune, where there was the biggest number of transactions in the analysed period, the data availability was in the range from $0 \%(2010,2014,2016)$ to $50 \%(2013)$. In the remaining communes, most often there is no information on the year of the finishing the building construction, which is presented in Table 2 .

Table 2. Data completeness of selected characteristics of transactions of buildings in Koszalin district communes in the years 2010-2016

\begin{tabular}{|c|c|c|c|c|c|c|c|c|c|}
\hline \multirow[b]{2}{*}{ Analysed quality } & \multirow[b]{2}{*}{ Commune } & \multicolumn{8}{|c|}{ Years of analysis - data completeness in $\%$} \\
\hline & & 2010 & 2011 & 2012 & 2013 & 2014 & 2015 & 2016 & $\begin{array}{c}\text { Average } \\
2010-2016\end{array}$ \\
\hline \multirow{8}{*}{$\begin{array}{l}\text { Usable area } \\
\text { of the building }\end{array}$} & Bobolice & 0 & 0 & 0 & 0 & 0 & 0 & 0 & \multirow{8}{*}{7} \\
\hline & Będzino & 0 & 0 & 0 & 0 & 0 & 0 & 0 & \\
\hline & Biesiekierz & 0 & 0 & 0 & 0 & 0 & 67 & 0 & \\
\hline & Świeszyno & 0 & 0 & 0 & 0 & 0 & 100 & 0 & \\
\hline & Sianów & 0 & 100 & 0 & 0 & 0 & 0 & 40 & \\
\hline & Mielno & 0 & 7 & 0 & 0 & 0 & 0 & 25 & \\
\hline & Manowo & 0 & 0 & 0 & 0 & 0 & 0 & 0 & \\
\hline & Polanów & 0 & 0 & 0 & 0 & 0 & 0 & 0 & \\
\hline \multirow{8}{*}{$\begin{array}{l}\text { Year of building } \\
\text { construction }\end{array}$} & Bobolice & 0 & 100 & 67 & 0 & 0 & 100 & 0 & \multirow{8}{*}{13} \\
\hline & Będzino & 0 & 0 & 0 & 0 & 0 & 0 & 0 & \\
\hline & Biesiekierz & 0 & 0 & 0 & 0 & 0 & 67 & 0 & \\
\hline & Świeszyno & 0 & 0 & 0 & 0 & 0 & 100 & 0 & \\
\hline & Sianów & 0 & 100 & 0 & 0 & 0 & 25 & 40 & \\
\hline & Mielno & 0 & 27 & 25 & 50 & 0 & 14 & 0 & \\
\hline & Manowo & 0 & 0 & 0 & 0 & 0 & 0 & 14 & \\
\hline & Polanów & 0 & 0 & 0 & 0 & 0 & 0 & 25 & \\
\hline \multirow{8}{*}{$\begin{array}{l}\text { Construction } \\
\text { material } \\
\text { of building walls } \\
\text { and the number } \\
\text { of storeys }\end{array}$} & Bobolice & 0 & 100 & 67 & 0 & 0 & 100 & 0 & \multirow{8}{*}{24} \\
\hline & Będzino & 0 & 100 & 0 & 0 & 0 & 100 & 0 & \\
\hline & Biesiekierz & 0 & 0 & 0 & 0 & 0 & 67 & 29 & \\
\hline & Świeszyno & 0 & 0 & 0 & 0 & 0 & 100 & & \\
\hline & Sianów & 0 & 100 & 0 & 0 & 0 & 100 & 40 & \\
\hline & Mielno & & 100 & 100 & 100 & 0 & 43 & 25 & \\
\hline & Manowo & 0 & 0 & 0 & 0 & 0 & 0 & 14 & \\
\hline & Polanów & 0 & 0 & 0 & 0 & 0 & 0 & 25 & \\
\hline
\end{tabular}

Source: author's own study.

Another analysed characteristics was the construction material of the building walls. When choosing in the real estate valuation process for comparison, it is important whether they were made of similar materials. Data availability in the analysed period is at the level of 24. Full data availability occurs in the register of Mielno commune in the years 2011-2013, Bobolice, Będzino, Sianów communes in 2011 and 2015, and in Świeszyno commune in 2015. The same 
availability of data was achieved when analysing the number of storeys in a building. Detailed data are presented in Table 2.

The lack of data in the whole analysed period occurs in the case of the technical condition of a building and the number of rooms.

Full completeness of data occurs in the case of transaction date, gross transaction price, real estate location, plot size, and the type of rights to the real estate. We can draw conclusions that the workers of district office in the analysed period reliably entered these data which are available in notarial deeds.

\section{Conclusions}

The completeness of data in the register of prices and values used for the valuation of parcels with residential function in Koszalin district communes in the years 2010-2016 varied. Full availability occurred in the case of transaction date, real estate location, plot size, and the type of rights to the real estate. It was at the level of 24 in the case of the construction material of building walls and the number of storeys. In the case of the building construction year, it was much lower and was about 13. It was even lower in the case of usable area -7 . The lack of data was marked in the case of the building technical conditions and the number of rooms. It is difficult to state whether the data quality changed in the analysed period of time, as the availability of data significantly differs between years. The biggest data collection is available for year 2015 and amounts to 41, the next is for year 2011 - around 30, while for others, the completeness is below 15 with the total lack of data for years 2010 and 2014.

Notarial deeds do not include enough data to be able to complete the register of prices and values in full on their basis. Therefore, it would be necessary to postulate the provision in the Notary Public Act which will oblige notaries to enter into the notary deed the required data concerning the real estate description when transferring the real estate ownership. The data should definitely be as follows: building usable area, building construction year, construction material of walls, number of storeys, net transaction price, real estate VAT.

The studied register of prices and values must be assessed as not really useful in terms of the completeness of data for real estate evaluation, mainly due to the lack of information about the building usable area. The other data are insufficient to let a real estate valuer make a proper choice on their basis of similar real properties, and analyse, among others, the characteristics influencing most the real property price. Perhaps the implementation of the Ordinance on the integrated system of information about real estate (The Ordinance, 2013), for which district 
offices have even up to 42 months from the date of the promulgation of the Act, will improve the situation. What is more, real estate valuers do not send excerpts from valuation surveys, which is the reason for which there are generally no data about a real estate value in this register.

The author is going to carry out broader research comprising neighbouring districts in the same time frame, among others in order to refer to this study.

\section{References}

Budzyński, T. (2012). Rejestr cen i wartość nieruchomości jako źródło danych dla potrzeb analizy rynku nieruchomości. Rzeczoznawca Majątkowy, 74 (2), 4-11.

Bydłosz, J., Cichociński, P., Parzych, P. (2010). Możliwości pokonania ograniczeń Rejestru cen i wartości nieruchomości za pomocą narzędzi Gis. Studia Informatica, 31 (2B 90), 229-243.

Foryś, I., Kokot, S. (2001). Problemy badania rynku nieruchomości. Zeszyty Naukowe Uniwersytetu Szczecińskiego. Studia i Prace Wydziału Nauk Ekonomicznych i Zarzadzania, 318.

Hopfer, A., Cegielski, S., Pietrzak, L. (2012). Rejestr cen i wartości nieruchomości w świetle projektu rozporządzenia RM w sprawie zintegrowanego systemu informacji o nieruchomościach - wpływ ww. rozporządzenia na jakość i wiarygodność RCIWN. Rzeczoznawca Majątkowy, 74 (2), 4-11.

Kokot, S. (2015). Jakość danych o cenach transakcyjnych na rynku nieruchomości. Acta Sci. Administratio Locorum, 14 (1), 43-29.

Konowalczuk, J. (2014). The corporate real estate market in public statistics in Poland. Real Estate Management and Valuation, 22 (2), 41-51.

The Ordinance of the Council of Ministers of 21 September 2004 on real estate valuation and preparation of valuation survey (Journal of Laws of 2007, item 2109 as amended).

The Ordinance of the Council of Ministers on the integrated system of information about real estate of 17 January 2013 (Journal of Laws of 2013, item 249).

The Ordinance of the Minister of Administration and Digitalisation of 5 September 2013 on the organisation and conditions of keeping the National Geodetic and Cartographic Resource (Journal of Laws of 2013, item 1183 as amended).

The Ordinance of the Minister of Administration and Digitalisation of 9 July 2014 on the access to the National Geodetic and Cartographic Resources, the issuance of licence and the template of Fee Calculation Document (Journal of Laws of 2014, item 917 as amended). 
The Ordinance of 10 June 2016 on the promulgation of the consolidated text of the Ordinance of the Minister of Regional Development and Construction, Warsaw (Journal of Laws of 2016, item 1034).

The Act of 23 April 1964, Civil Code (consolidated text Journal of Laws of 2017, item 459, Art. 232-243).

The Act of 17 May 1989, Surveying and Cartographic Law (Journal of Laws of 2015, item 520 as amended).

The Notary Public Act of 14 February 1991 (Journal of Laws of 1991 No. 22, item 91, as amended).

Real Property Management Act of 21 August 1997 (Journal of Laws of 2014, item 518 as amended).

Personal Data Protection Act of 29 August 1997 (Journal of Laws of 2015, item 2135 as amended).

Stamp Duty Act of 16 November 2006 (Journal of Laws of 2015, item 783 as amended). 